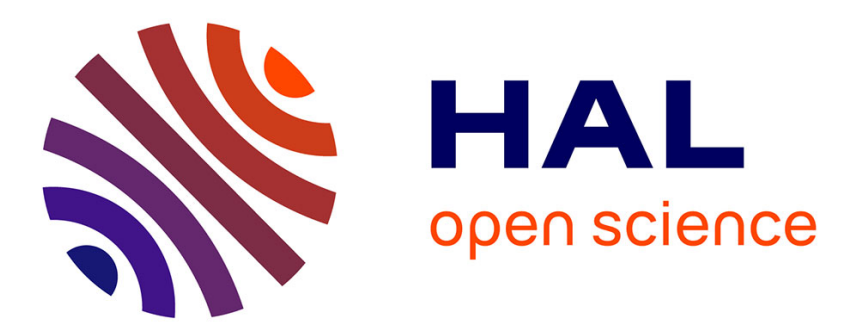

\title{
Field Desorption Pathways of Water during the H2- Oxidation on a Pt Field Emitter
}

\author{
W. Drachsel, C. Wesseling, V. Gorodetskii
}

\section{To cite this version:}

W. Drachsel, C. Wesseling, V. Gorodetskii. Field Desorption Pathways of Water during the H2Oxidation on a Pt Field Emitter. Journal de Physique IV Proceedings, 1996, 06 (C5), pp.C5-31-C536. 10.1051/jp4:1996504 . jpa-00254383

\section{HAL Id: jpa-00254383 https://hal.science/jpa-00254383}

Submitted on 1 Jan 1996

HAL is a multi-disciplinary open access archive for the deposit and dissemination of scientific research documents, whether they are published or not. The documents may come from teaching and research institutions in France or abroad, or from public or private research centers.
L'archive ouverte pluridisciplinaire HAL, est destinée au dépôt et à la diffusion de documents scientifiques de niveau recherche, publiés ou non, émanant des établissements d'enseignement et de recherche français ou étrangers, des laboratoires publics ou privés. 
JOURNAL DE PHYSIQUE IV

Colloque C5, supplément au Journal de Physique III, Volume 6, septembre 1996

\title{
Field Desorption Pathways of Water during the $\mathrm{H}_{2}$ - Oxidation on a Pt Field Emitter
}

\author{
W. Drachsel, C. Wesseling and V. Gorodetskii* \\ Fritz-Haber-Institut der Max-Planck-Gesellschaft, Faradayweg 4-6, 14195 Berlin, Germany \\ * Boreskov Institute of Catalysis, 630090 Novosibirsk, Russia
}

\begin{abstract}
Using the field ion microscope as a flow reactor the catalytic oxidation of hydrogen by $\mathrm{O}_{2}$ on $\mathrm{Pt}$ has been studied by the ToF coincidence technique. The "imaging ions" consist mainly of $\mathrm{H}_{3} \mathrm{O}^{+}$, less $\mathrm{H}_{2} \mathrm{O}^{+}$and to some extent fieid and coverage sensitive $\mathrm{O}_{2}{ }^{+}$species. The product ion spectrum qualitatively coincides with that of pure water field desorbed at $300 \mathrm{~K}$. On the oxygen side of the $\mathrm{H}_{2} / \mathrm{O}_{2} / \mathrm{Pt}$ system, $\mathrm{H}_{3} \mathrm{O}^{+}$is formed by the field induced disproportionation of two water molecules leaving behind an $\mathrm{OH}_{\mathrm{ad}}$.

For the system $\mathrm{H}_{2} \mathrm{O} / \mathrm{Pt}$, the observed emission of $\mathrm{O}_{2}{ }^{+}$during field ionisation is striking in so far as $\mathrm{O}_{2}$ recombination at $300 \mathrm{~K}$ is improbable. To clarify the nature of the precursor of this reaction channel a coincidence experiment was performed and a simultaneous emission of $\mathrm{O}_{2}^{+}$and $\mathrm{H}_{3} \mathrm{O}^{+}$ions from the same site was detected. We propose the following disproportionation for this step: a hydroxyl forms a transition complex with a peroxy-surface species, which then desintegrates into molecular oxygen and hydronium, which emit as $\mathrm{O}_{2}{ }^{+}$and $\mathrm{H}_{3} \mathrm{O}^{+}$in the field. During the ongoing hydrogen oxidation this coincidence is also observed on the oxygen side of the reaction; on the hydrogen side of the reaction no coincidence is observed, as in this case the pathway $\mathrm{H}_{\mathrm{ad}}+\mathrm{H}_{2} \mathrm{O}^{+}{ }_{\mathrm{ad}} \rightarrow \mathrm{H}_{3} \mathrm{O}^{+}$ is predominant.
\end{abstract}

\section{INTRODUCTION}

Two aspects prompted us to investigate heterogeneous catalytic reactions in situ by field related methods:

(i) the field emitter tip appears to be a suitable model of a catalyst grain with respect to size and shape and

(ii) the direct observation of "reactive sites" on an atomic scale by field ion microscopy (FIM) is feasable as demonstrated recently [1].

Concerning the hydrogen oxidation by $\mathrm{O}_{2}$ the latter point becomes even more advantageous as the reaction product water will field-desorb as $\mathrm{H}_{3} \mathrm{O}^{+}$. Thus, the field ion image during the ongoing reaction directly displays a map of the local reaction rate, while additional information about the surface coverage of the educts can be extracted from the corresponding field electron micrographs [2].

The reaction kinetics of the hydrogen oxidation on Pt under field conditions at applied field strenghts of $1.5 \mathrm{~V} / \AA$ in the FIM can involve isothermal oscillations at distinct control parameters $[2,3]$. The product water is field-desorbed mainly as $\mathrm{H}_{3} \mathrm{O}^{+}$[4]. This desorption channel under field conditions releases oxygen from stochiometric reasons on the oxygen side of the reaction. This becomes even more obvious if the field desorption (FD) spectrum of pure water is analyzed $[5,6]$. One concern of this contribution is to uncover the field induced pathways for oxygen formation. Basic information on the energetics for the FD-channels are given by the work of Ernst et al., investigating the systems $\mathrm{H}_{2} / \mathrm{H}_{2} \mathrm{O}$ and $\mathrm{H}_{2} / \mathrm{O}_{2}$ on Pt by measuring the appearance energy of the product ions $[4,7]$.

In present experimental work we looked alternatively for the correlated formation of product field ions for $\mathrm{H}_{2} / \mathrm{O}_{2}$ and $\mathrm{H}_{2} \mathrm{O}$ on $\mathrm{Pt}$ to deduce field induced reaction pathways and evidence for intermediates of the reaction. 


\section{PREVIOUS WORK}

Since 1822, when Döbereiner discovered the cold combustion of $\mathrm{H}_{2}$ by dispersed $\mathrm{Pt}$, the kinetics of the hydrogen-oxygen reaction has been studied by many groups. A review is given by Norton [8]. There is a general agreement that the reaction follows a Langmuir-Hinshelwood mechanism according to the steps (1) to (3) (* means an empty site).

$$
\begin{aligned}
& \mathrm{H}_{\mathrm{ad}}+\mathrm{O}_{\mathrm{ad}} \longrightarrow \mathrm{OH}_{\mathrm{ad}}+* \\
& \mathrm{H}_{\mathrm{ad}}+\mathrm{OH}_{\mathrm{ad}} \longrightarrow \mathrm{H}_{2} \mathrm{O}_{\mathrm{ad}}+* \\
& \mathrm{OH}_{\mathrm{ad}}+\mathrm{OH}_{\mathrm{ad}} \longrightarrow \mathrm{H}_{2} \mathrm{O}_{\mathrm{ad}}+\mathrm{O}_{\mathrm{ad}}
\end{aligned}
$$

The reaction starts even above $120 \mathrm{~K}$ [9] on $\mathrm{Pt}$, which is well below the desorption temperature of $\mathrm{H}_{2} \mathrm{O}^{+}$at $180 \mathrm{~K}$. At higher temperatures the water, after formation, will desorb from an equilibrated state, as indicated by the cosine-angular distribution of the desorbing molecules [10].

The water synthesis on Pt has been studied in the limit of low coverages [11] and also in the limit of high coverages [12], where the interaction of adjacent adspecies shifts the activation energies to lower values.

Collective phenomena are also observed in the FIM: during isothermal oscillations of the reaction rate the propagation of reaction diffusion fronts across adjacent crystal planes becomes visible [2]. These fronts are distinguished by high rates of water synthesis, expressed by a high $\mathrm{H}_{3} \mathrm{O}^{+}$emission in the presence of a field. At the so called oxygen side of the reaction $\left(\Theta\left(\mathrm{O}_{a d}\right)>\Theta\left(\mathrm{H}_{\mathrm{ad}}\right)\right)$ [19] the hydronium ions are formed by the reaction scheme:

$$
2 \mathrm{H}_{2} \mathrm{O}^{+} \mathrm{f}-\mathrm{ad} \stackrel{\text { field }}{\longrightarrow} \mathrm{H}_{3} \mathrm{O}^{+} \text {gas }+\mathrm{OH}_{\mathrm{ad}}+\mathrm{e}^{-}{ }_{\mathrm{Pt}}+*
$$

The hydroxyls will then further react according to step (2) or (3), forming oxygen species.

In the case of the FD of water the same reaction steps are relevant. The formation of an $\mathrm{O}_{\mathrm{ad}}$-layer on $\mathrm{Pt}$ is expected according to the $\mathrm{FD}$ of $\mathrm{H}_{3} \mathrm{O}^{+}$following reaction (4) and successive step (3). After having applied a field $>1.2 \mathrm{~V} / \AA$ at $300 \mathrm{~K}$ during the exposure of the tip to $\mathrm{H}_{2} \mathrm{O}_{\text {gas }}$ this was verified by titration with $\mathrm{H}_{2}$ in the field electron and field ion microscope [13].

The emission of $\mathrm{O}_{2}{ }^{+}$during field desorption of pure water from $\mathrm{Pt}$ at $300 \mathrm{~K}$ [6], however, cannot be explained by recombination of thermally equilibrated $\mathrm{O}_{\mathrm{ad}}$-species. If now equation (4) is formulated in a stochiometric way (5), a correlated emission of $\mathrm{H}_{3} \mathrm{O}^{+}$and $\mathrm{O}_{2}+$ might be expected (5a).

$$
\begin{aligned}
6 \mathrm{H}_{2} \mathrm{O}_{\mathrm{f} \text {-ad }} \stackrel{\text { field }}{\longrightarrow} 3 \mathrm{H}_{3} \mathrm{O}^{+}+ & 3 \mathrm{OH}_{\mathrm{ad}}+3 \mathrm{e}^{-} \mathrm{Pt}+3 * \\
& \stackrel{\text { field }}{\longrightarrow} \mathrm{H}_{3} \mathrm{O}^{+}+\mathrm{O}_{2}^{+}+2 \mathrm{e}^{-} \mathrm{Pt}+2 *
\end{aligned}
$$

The alternative formation of $\mathrm{H}_{3} \mathrm{O}^{+}$by protonation as observed for the hydrogen side of the reaction $\left(\Theta\left(\mathrm{O}_{\mathrm{ad}}\right)<\Theta\left(\mathrm{H}_{\mathrm{ad}}\right)\right)$ will be discussed in detail by Sieben et al. in this volume [19].

\section{EXPERIMENTAL}

The details of the experimental setup are given in [14]. In short: The FI microscope with probe hole mass and correlation analysis was used. The purified gases were introduced at a constant flow. The pressure control system kept the partial pressures of $\mathrm{H}_{2}$ and $\mathrm{O}_{2}$ or $\mathrm{H}_{2} \mathrm{O}$ within $1 \%$, the temperature of the (001) oriented Pt field emitter was controlled within $0.1 \mathrm{~K}$. The Pt emitter tip was cleaned by field evaporation and characterized by neon imaging (Fig. 1a). During the reaction (Fig. 1b), the field ion image was recorded by a CCD video camera, the chemical identification of field-desorbed ions passing the probe hole can be achieved by mass separation (Wien filter, $\mathrm{m} / \Delta \mathrm{m} \approx 10$ ) [15]. Surface species were also field desorbed by pulsed laser irradiation (pulse width $10 \mathrm{ns)}$ and mass analyzed by time of flight measurements [14]. The time correlation of emitted ions was measured with a fast clock. This clock was started by the arrivel of a light ion and stopped by the arrivel of the next heavy one [16]. To achieve a better signal to noise ratio the ions were mass separated by the Wien filter and separately detected. In this mode the laser is not active. 

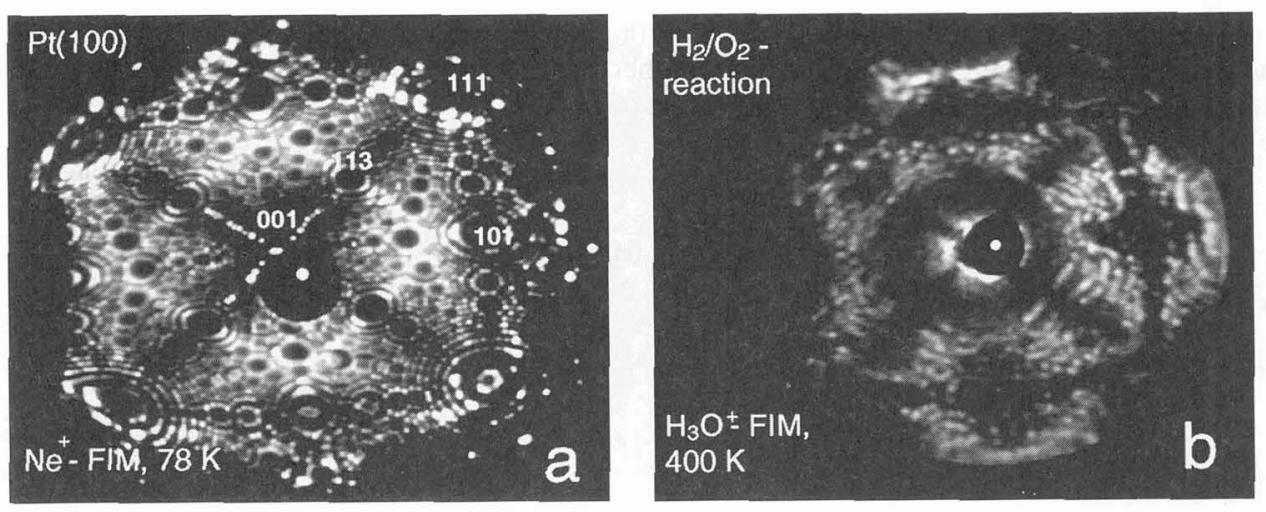

Figure 1: FI image of the (100) Pt emitter, white dot in black center: probe hole
(a) neon, $78 \mathrm{~K}$
(b) during $\mathrm{H}_{2} / \mathrm{O}_{2}$-reaction, $\mathrm{T}=400 \mathrm{~K}, \mathrm{~F}=1.2 \mathrm{~V} / \AA$

\section{RESULTS AND DISCUSSIONS}

According to the reaction (4) followed by step (3) we have searched for a correlated emission of ion pairs like: $\mathrm{H}_{3} \mathrm{O}^{+}, \mathrm{O}^{+}$or $\mathrm{H}_{2} \mathrm{O}^{+}, \mathrm{O}^{+}$or the two water species $\mathrm{H}_{3} \mathrm{O}^{+}, \mathrm{H}_{2} \mathrm{O}^{+}$, for both reaction systems: $\mathrm{H}_{2} \mathrm{O} / \mathrm{Pt}$ and $\mathrm{H}_{2} / \mathrm{O}_{2} / \mathrm{Pt}$. It turned out that all these emission events were statistically independent of each other at a time scale of ns.

The $\mathrm{H}_{3} \mathrm{O}^{+}$and $\mathrm{O}_{2}+$ emission, however, was correlated for $\mathrm{H}_{2} \mathrm{O} / \mathrm{Pt}$ (Fig. 2a). The sharp peak at $667.2 \mathrm{~ns}$ on top of randomized pair events exactly corresponds with the difference of flight times $\left(\Delta \mathrm{t}_{\mathrm{f}}\right)$ of these ions. The absolute flight times $t_{f}$ are known from pulsed laser field desorption experiments.

Doing the same measurment during ongoing $\mathrm{H}_{2}$ oxidation, the same correlation (Fig. 2b) is observed at the oxygen side of the reaction. The tailing of the correlation peak is less developed, and a small additional peak can be identified as the simultaneous emission of $\mathrm{H}_{3} \mathrm{O}^{+}$and $\mathrm{HO}_{2}{ }^{+}$. Within the experimental error the coincidence of emission of $\mathrm{H}_{3} \mathrm{O}^{+}$and $\mathrm{O}_{2}{ }^{+}$occurs from the selected site within less than $100 \mathrm{ps}$. Therefore, we conclude that these $\mathrm{H}_{3} \mathrm{O}^{+}$and $\mathrm{O}_{2}{ }^{+}$species are originating from the same transition complex. To get an indication of its nature, we analysed the pulsed laser field desorption spectrum, as obtained during $\mathrm{H}_{2} / \mathrm{O}_{2}$ reaction (Fig. 3).

The minority species are identified as $\mathrm{OH}^{+}, \mathrm{HO}_{2}{ }^{+}$and $\mathrm{H}_{2} \mathrm{O}_{2}{ }^{+}$, which were also detected in the water $\mathrm{FD}$ spectrum by Schmidt [6]. The peroxy complex $\mathrm{H}_{2} \mathrm{O}_{2}$ as an intermediate in $\mathrm{H}_{2}$ oxidation has been already proposed by Verheij et al. [17] who investigated the reaction on $\mathrm{Pt}(111)$ by modulated molecular beam transient spectroscopy.

Field adsorbed water agglomerates even at room temperature at the surface, as expressed by the emission of protonated water cluster ions as a minority route, and as well by the formation of $\mathrm{H}_{3} \mathrm{O}^{+}$from two water molecules in step (4) and not by the energetically more favoured direct protonation, as is prevailing on the hydrogen side of the reaction or for the $\mathrm{H}_{2} / \mathrm{H}_{2} \mathrm{O}$ system [4]. From these findings we conclude that the hydroxyls are formed in close vicinity, and that the peroxy complex emerges from two $\mathrm{OH}_{\mathrm{ad}}$. We explain the simultaneous emission of $\mathrm{H}_{3} \mathrm{O}^{+}$and $\mathrm{O}_{2}{ }^{+}$for the studied reaction systems by the following disproportionation:

$$
\mathrm{OH}_{\mathrm{ad}}+(\mathrm{OH} \ldots . \mathrm{OH})_{\mathrm{ad}} \stackrel{\text { field }}{\longrightarrow} \mathrm{H}_{3} \mathrm{O}^{+}+\mathrm{O}_{2}{ }^{+}+2 \mathrm{e}_{\mathrm{Pt}}^{-}
$$

This should not be misinterpreted as a triple collision $\left(\mathrm{H}_{2} \mathrm{O}\right.$ is also formed in successive steps from $\mathrm{H}_{\mathrm{ad}}$. $\mathrm{H}_{\mathrm{ad}}$ and $\mathrm{O}_{\mathrm{ad}}$ ). By changing the probe hole position, we found out that only the reactive sites (bright in FIM 
image) emitted $\mathrm{H}_{3} \mathrm{O}^{+}$and $\mathrm{O}_{2}{ }^{+}$simultaneously; the nature of these sites is still obscure. If the reaction switches to the hydrogen side (by applying higher hydrogen pressures), no correlation is detected any more, in agreement with the observed protonation of $\mathrm{H}_{2} \mathrm{O}$ by $\mathrm{H}$ as discussed in Ref. [19].

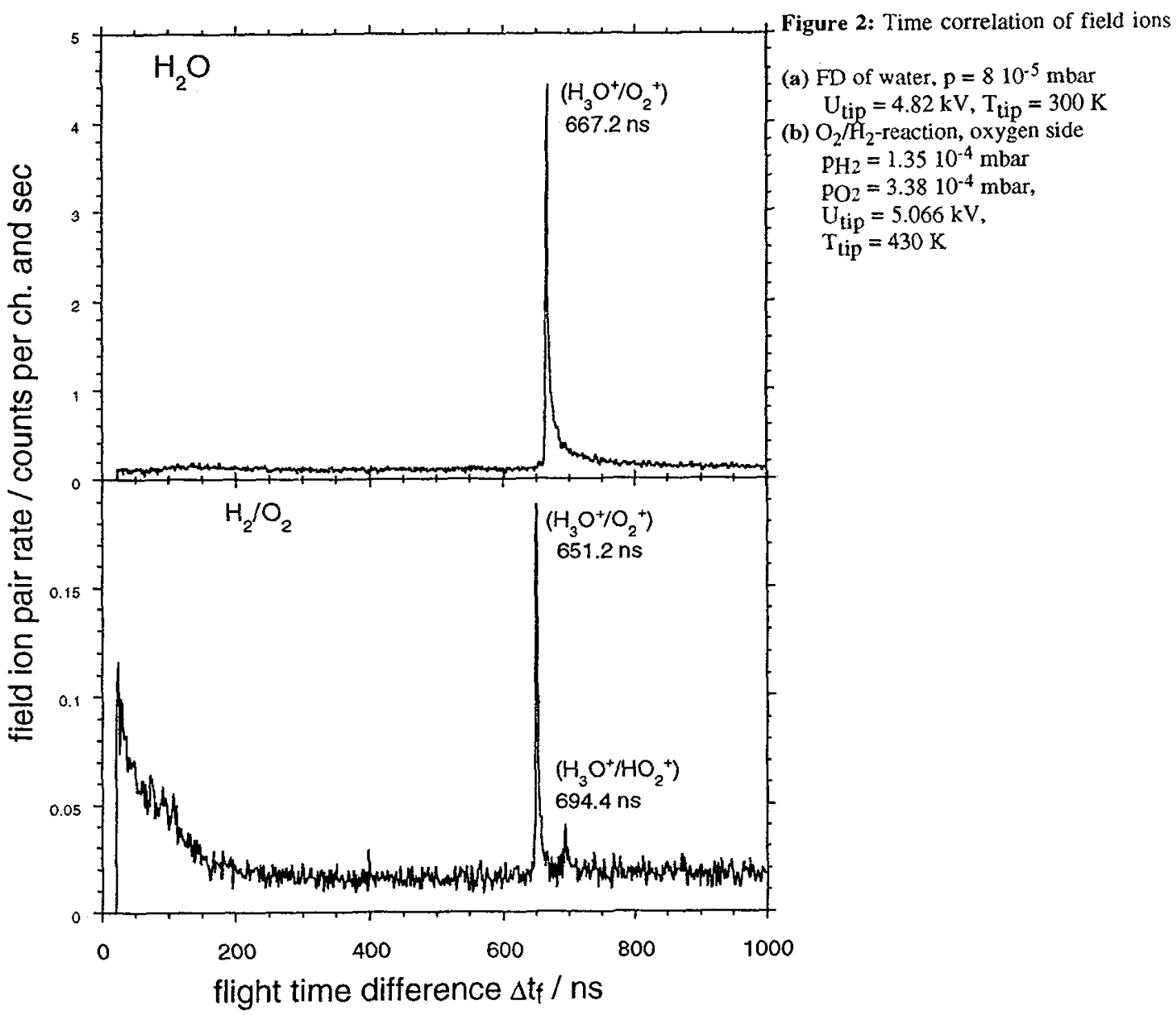

Resuming the interpretation of the simultananous ion emission events, a formation of $\mathrm{O}_{2}{ }^{+}$from two hot $\mathrm{O}_{\mathrm{ad}}$ may be conceived alternatively. Hot means that a fraction of the reaction enthalpy is released as kinetic energy of $\mathrm{O}_{\mathrm{ad}}$. For FD of water, $\mathrm{O}_{\mathrm{ad}}$ can be exclusively produced by step (3). An $\mathrm{H}_{2} \mathrm{O}$ may react immediately with a neighbouring one according to reaction (4) involving $\mathrm{FD}$ of $\mathrm{H}_{3} \mathrm{O}^{+}$. The $\mathrm{OH}_{\mathrm{ad}}$ may be attached to an $\mathrm{O}_{\mathrm{ad}}$ to form the minority species $\mathrm{HO}_{2}{ }^{+}$as observed in Fig. 2b. Raising the temperature to $400 \mathrm{~K}$ for the $\mathrm{H}_{2} / \mathrm{O}_{2} / \mathrm{Pt}$ system the emission of ion pairs $\mathrm{H}_{3} \mathrm{O}^{+}, \mathrm{HO}_{2}+$ is also detected at low intensities. If $\mathrm{O}_{2}{ }^{+}$would emerge from fragmentation of $\mathrm{HO}_{2}{ }^{+}$, one cannot explain the observability of $\mathrm{HO}_{2}{ }^{+}$in the coincidence spectrum appearing only above $400 \mathrm{~K}$.

A direct formation of $\mathrm{O}_{2}{ }^{+}$from hot $\mathrm{O}_{a d}$ with a minimum of steps can be conceived. Two $\mathrm{H}_{2} \mathrm{O}_{\mathrm{ad}}$ are produced adjacently according (3) from 4 hydroxyls, and then the $\mathrm{O}_{\mathrm{ad}}$ recombine. At the same instant $\mathrm{H}_{3} \mathrm{O}^{+}$ could be formed by the disproportionation (4).If $\mathrm{H}_{3} \mathrm{O}^{+}$and $\mathrm{O}_{2}+$ were formed in individual steps each, then the tailing of the coincidence would be symmetric in time. But only a delay for $\mathrm{O}_{2}{ }^{+}$emission is observed. If this model is correct the $\mathrm{H}_{2} \mathrm{O}$ diffusion to form the water dimer and the disproportionation in sequence would be very fast compared to the recombination of the two hot $\mathrm{O}_{\mathrm{ad}}$ within the time scale of some hundred picoseconds.

It has to be stressed that the correlated $\mathrm{O}_{2}{ }^{+}$formation is only a minority route, more than $90 \%$ of the $\mathrm{O}_{2}{ }^{+}$ current is uncorrelated as is derived from an analysis of the statistical background in Fig. 2a. For these ions a formation from thermally equilibrated $\mathrm{O}_{\mathrm{ad}}$ is not possible at these temperatures, but as indicated before, 


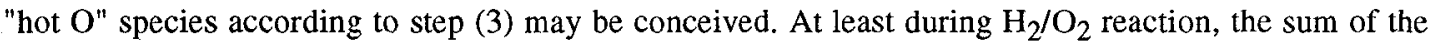
emitted $\mathrm{H}_{2} \mathrm{O}^{+}$appear to carry up to $0.6 \mathrm{eV}$ translational surplus energy with it, as the appearance energy data show [7].

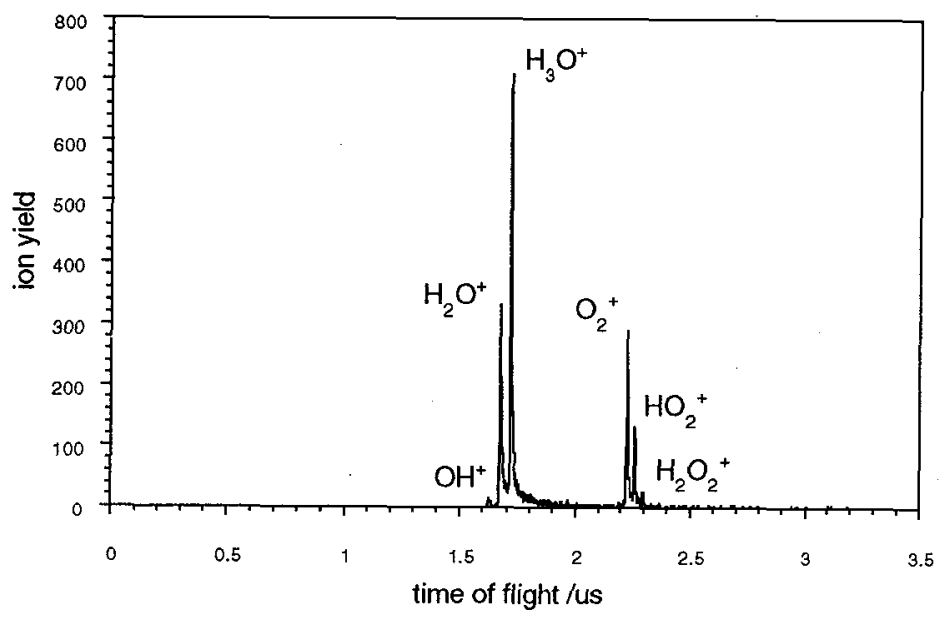

Figure 3:Pulsed laser FD during reaction $\mathrm{P}\left(\mathrm{O}_{2}\right)=2.210^{-4} \mathrm{mbar}$ $\mathrm{P}\left(\mathrm{H}_{2}\right)=1.0110^{-4}$ mbar $\mathrm{T}=400 \mathrm{~K}, \mathrm{U}_{\mathrm{tip}}=8.2 \mathrm{kV}$

During the $\mathrm{H}_{2} / \mathrm{O}_{2}$-reaction $\mathrm{O}_{2}{ }^{+}$is also formed directly by field ionisation with a rate depending sensitively on the applied field. From the $\mathrm{CO} / \mathrm{O}_{2}$-system [1] we know that oxygen is preferentially field ionised above oxygen-covered $\mathrm{Pt}$, explained by a resonance effect [18].

The effect is even more predominant during the $\mathrm{H}_{2}$-oxidation due to consumption of the impinging $\mathrm{O}_{2}$. At a high reaction rate the surface offers more empty sites for dissociative adsorption whereas at low reactivity the field ionisation probability is increased for repelling oxygen. This "anticorrelation" of $\mathrm{H}_{3} \mathrm{O}^{+}$product ion rate and $\mathrm{O}_{2}{ }^{+}$current can be seen in Fig. 4.

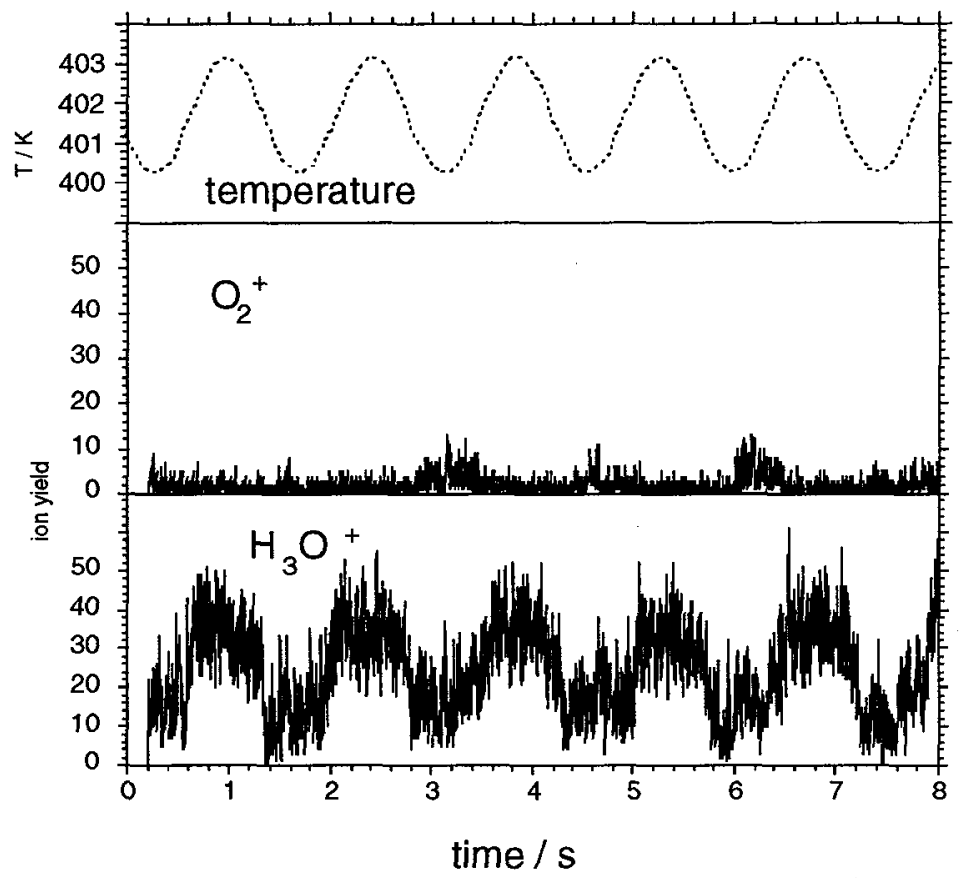

Figure 4: Rate oscillations by temperature modulation $\mathrm{p}\left(\mathrm{O}_{2}\right)=4.310^{-4} \mathrm{mbar}$ $\mathrm{p}\left(\mathrm{H}_{2}\right)=1.310^{-4} \mathrm{mbar}$ $\mathrm{F}_{\text {tip }}=1.2 \mathrm{~V} / \AA$ 
In the instable range of the reaction, the temperature was modulated sinusoidally by a small increment of $2 \mathrm{~K}$ around $400 \mathrm{~K}$, which forced the reaction rate to oscillate in phase. At a low local production rate the corresponding local oxygen rate is higher (second trace) as during the time of high chemical activity.

In conclusion, the reaction pathway leading to an $\mathrm{O}_{2}+$-abundance in the field ion spectrum of the $\mathrm{H}_{2} \mathrm{O}-\mathrm{Pt}$ and the $\mathrm{O}_{2} / \mathrm{H}_{2}-\mathrm{Pt}$ system are a consequence of the preferential $\mathrm{H}_{3} \mathrm{O}^{+}$emission under field conditions due to the proportionation reaction of two adjacent $\mathrm{H}_{2} \mathrm{O}$ molecules. A peroxy intermediate or a recombination of non-equilibrated $\mathrm{O}$ species as precursors are proposed.

\section{References}

[1] Gorodetskii, V., Drachsel, W. and Block, J.H., Appl. Surf. Sci. $76 / 77$ (1994) 122-128.

[2] Gorodetskii, V., Block, J.H. and Drachsel, W., Appl. Surf. Sci. 76/77 (1994) 129-135.

[3] Drachsel, W., Gorodetskii, V. and Block, J.H., Appl. Surf. Sci. 76/77 (1994) 70-72.

[4] Ernst, N., Bozdech, G., Gorodetskii, V., Kreuzer, H.J., Wang, R.L.C., Block, J.H., Surf. Sci. 318 (1994) L1211.

[5] Beckey, H.D., Z. Naturforsch., Teil A, 14 (1959) 712.

[6] Schmidt, W.A., Z. Naturforsch., Teil A, 19 (1964) 318.

[7] Ernst, N., Bozdech, G., Gorodetskii, V. and Block, J.H., Int. J. Mass Spec. Ion Proc., 152 (1996) 185

[8] Norton, P.R. in "The Chemical Physics of Solid Surfaces and Heteregeneous Catalsis", D.A.

King and D.P. Woodruff Eds. (Elsevier, Amsterdam, 1982) Vol. 4, p. 27.

[9] Kwasniewski, V.J., Schmidt, L.D., J. Chem. Phys. 96 (1992) 5931.

[10] Padowtz, D.F., Siebener, S.J., Surf. Sci. 254 (1991) 125.

[11] Anton, A.B. and Cadogan, D.C., Surf. Sci. 239 (1990) L548.

[12] Hellsing, B., Kasemo, B., Zhdanov, V.P., J. Cat. 132 (1991) 210.

[13] Gorodetskii, V., Ernst, N., Drachsel, W. and Block, J.H., Appl. Surf. Sci. 87/88 (1995) 151.

[14] Drachsel, W., Jentsch, Th., and Block, J.H., Int. J. Mass. Spec. Ion Phys. 46 (1983) 293.

[15] Drachsel, W. and Block, J.H., Surf. Sci. 246 (1991) 141.

[16] Block, J.H., Dirks, J., Drachsel, W., Rev. Lat. Met. Mat. 11 (1992) 39.

[17] Verheij, L.K., Freitag, M., Hugenschmidt, M.B., Kempf, I., Poelsema, B. and Comsa, G., Surf. Sci. 272 (1992) 276.

[18] Kreuzer, H.J., Z. Phys. Chem., submitted.

[19] Sieben, B., Bozdech, G., Ernst, N., this volume 